\title{
Medievalista
}

Online

$9 \mid 2011$

Número 9

\section{O Clero Secular Medieval e as suas Catedrais. Novas Perspectivas e Abordagens}

\section{Maria Leonor Botelho}

\section{(2) OpenEdition}

1 Journals

Edição electrónica

URL: http://journals.openedition.org/medievalista/668

DOI: 10.4000/medievalista.668

ISSN: 1646-740X

\section{Editora}

Instituto de Estudos Medievais - FCSH-UNL

\section{Refêrencia eletrónica}

Maria Leonor Botelho, «O Clero Secular Medieval e as suas Catedrais. Novas Perspectivas e Abordagens », Medievalista [Online], 9 | 2011, posto online no dia 02 janeiro 2011, consultado o 15 setembro 2020. URL : http://journals.openedition.org/medievalista/668

Mediavalista está Internacional. 
Titulo: O Clero Secular Medieval e as suas Catedrais. Novas Perspectivas e Abordagens.

Autor(es): Maria Leonor Botelho

Enquadramento Institucional: Membro IEM, Faculdade de Ciências Sociais e Humanas, Universidade Nova de Lisboa.

Contacto: leonorbotelho@gmail.com

Fonte: Medievalista [Em linha]. №9, (Dezembro 2010). Direc. José Mattoso. Lisboa: IEM. Disponível em: http://www2.fcsh.unl.pt/iem/medievalista/ ISSN: 1646-740X

\section{- Clero Secular Medieval e as suas Catedrais. Novas Perspectivas e Abordagens}

\section{Maria Leonor Botelho}

Realizou-se recentemente a $1^{\text {a }}$ Sessão do Encontro Internacional consagrado ao estudo do Clero Secular Medieval e as suas Catedrais e que contou com a presença de diversos especialistas nacionais e estrangeiros que abordaram diversos aspectos relacionados com a Liturgia, a Música e Arte e a Arquitectura no âmbito das catedrais portuguesas e com a Sigilografia, a Tumularia, a Heráldica e a Epigrafia já no contexto eclesiástico nacional. 
Procurando dar uma nova visibilidade, e apostando na continuidade, dos trabalhos de investigação sobre estas matérias, os seus vários painéis, quer no respeitante à Liturgia e Espaço Religioso, quer no relativo aos Símbolos e Representações do Poder revelaram novos contributos e novas linhas de investigação nestas matérias. Os workshops, consagrados ao Património catedralício edificado: funções, transformações e restauros e aos Símbolos e representações do poder: projectos de futuro, revelaram-se igualmente de uma extrema pertinência e actualidade pelos debates gerados e pelas ideias e conceitos apresentados durante as sessões.

De um modo geral, os especialistas da matéria apelaram à criação de uma entidade fiscalizadora que velasse pelo melhor entendimento das várias tutelas que se associam ao património catedralício (mas também a outros patrimónios), assim como apelaram a um maior entendimento entre o meio académico e cientifico e as entidades responsáveis pela gestão, salvaguarda e divulgação desse mesmo património catedralício, aos mais diversos níveis.

Encontros como este, multidisciplinares, revelam a importância crescente do cruzamento de dados necessário entre as várias disciplinas afins que, em vez de caminhar paralelamente, devem antes cruzar os seus dados, no sentido de compreender melhor o todo na sua unicidade.

Esperemos agora que a $2^{\text {a }}$ Sessão deste encontro, que decorrerá nos dias 1 e 2 de Abril de 2011, consagrada já ao tema das Culturas, conheça a mesma dinâmica e sucesso, no estudo que se centrará já sobre a Cultura Material e Cultura Intelectual. Assim, estarão na ordem do dia as áreas relacionadas com a materialidade e a mundividência do quotidiano do clero secular medievo, destacando a sua importante vertente cultural e intelectual. 


\section{COMO CITAR ESTE ARTIGO}

\section{Referência electrónica:}

BOTELHO, Maria Leonor - O Clero Secular Medieval e as suas Catedrais. Novas Perspectivas e Abordagens. Medievalista [Em linha]. №9, (Dezembro de 2010). [Consultado dd.mm.aaaa]. Disponível em http://www2.fcsh.unl.pt/iem/medievalista/MEDIEVALISTA9lbotelho9012.html. ISSN 1646-740X.

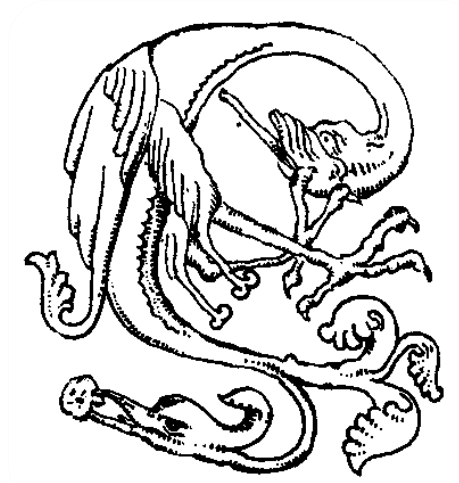

